IKO $70 \AA ̊ R$

SOMMERFEST I COLLETTSGATE 43, 26. AUGUST 2015

\title{
I skjæringspunktet mellom kirke og samfunn
}

\author{
Av FinN WAgLE
}

Kjære IKO-venner og IKO-medarbeidere, Gratulerer med 70-årsjubileet! Guds fred over sommerfesten her i eventyrslottet i Collettsgate!

Jeg husker godt da IKO våren 1988 flyttet fra trangbodde lokaler i Oslo sentrum opp hit til St. Hanshaugen. Bare de ni siste månedene av min tid som leder av IKO var vi her. Men for meg står disse månedene $\mathrm{i}$ et helt spesielt lys. Derfor er det først og fremst dette stedet jeg forbinder med mine år ved IKO. Her var det godt å være. Her kunne vi puste friere. Her kunne vi samle krefter og sette sammen medarbeiderteam som skulle besøke lærerstevner, utdanningsinstitusjoner, barnehager, skoler og menigheter. Ja, her kunne kreativitet utfoldes, på jakt etter å virkeliggjøre det som vi den gangen formulerte som IKOs visjon: Kristen tro og kulturtradisjon til neste generasjon! Men på ett punkt var vi ikke så kreative som dere er: Vi tok ikke hagen i bruk, slik det skjer i dag.

\section{IKO - ET UREGELMESSIG VERB}

Det kan henge sammen med at hagen den gangen mer var som et villniss, om jeg husker rett. I dag har dere invitert oss til fest i en vakker og velstelt hage. Ikke en strengt anlagt hage etter fransk mønster. Men mer som en engelsk hage, hvor blomster og trær får gro friere. Dermed uttrykker denne hagen noe av det som allid har vært en del av IKOs sjel: IKO har aldri villet la seg innpasse i den strengt anlagte byråkratiske kirke-hage. IKO hører hjemme i en hage hvor blomster og trær får gro og vokse friere, der det finnes spirekraft.

Hva er det som gjør IKO til en sjelden blomst i kirke-hagen, for ikke å si et uregelmessig verb? Det handler bl.a. om at her setter offisielle og frivillige arbeidslag i kirken hverandre stevne. Ja, jeg vet ikke om noe annen virksomhet i kirken som gjennom sin organisasjonsform speiler vårt sammensatte og mangfoldige kirkebilde som nettopp IKO.

KORT HISTORISK TILBAKEBLIKK

Det er klart at vi på en dag som denne må bruke litt tid på å se oss bakover. Ikke for å dvele ved IKOs historie i og for seg. Poenget må være å se hva vi kan lære av denne historien, når vi i dag skal se fremover. Olav Duun lar en av sine romanskikkelser si: «Du er som roaren, han òg sit og snur seg galne vegen kan du ikkje heller sjå fram! Å sjå fram - det er det vi skal bruke historien til i dag.

Det første som da slår oss, er hvilke enorme samfunnsmessige endringer som har skjedd siden Bjarne Hareide etablerte «Kristelig pedagogisk kontor» for å gjenreise kristendomsfaget i skolen i 1945. I 1948 ble navnet endret til IKO - Institutt for Kristen 
Oppseding. Oppgaveporteføljen ble samtidig utvidet til det IKO vi kjenner i dag med barnehage, skole, hjem/familie og kirke/menighet.

I 1952 ble så IKOs Læremidler etablert for å drive forlags- og læremiddelvirksomhet, nærmest som en støttefunksjon for instituttet. I 1985 endret virksomheten navn til IKOForlaget. Da er vi fremme ved min egen tid. For meg er det spennende å sammenlikne IKO på 1980-tallet med IKO slik virksomheten fremstår i dag. Jeg mer enn aner at det har skjedd en klar tyngdepunktforskyvning mellom institutt (eller senter, som det heter i dag) og forlag. Forlaget spiller en betydelig større rolle enn tidligere. Nye arbeidsformer har dessuten kommet til. Og ikke minst: Dåpsklubben TRIPP TRAPP har blitt en viktig faktor i dåpsopplæringen på hjemmebane. Nye samarbeidsrelasjoner er også et trekk i det store bildet. Et nærliggende eksempel er samarbeidet med Kirkerådet om den årlige trosopplærings-konferansen.

\section{IKO I SKJÆRINGSPUNKTET MELLOM KIRKE OG SAMFUNN}

Tilbake til historien: Hva kan vi i dag lære av IKOs historie, når utfordringen lyder: Sjå fram! Da vil jeg ta utgangspunkt i det som i alle år har vært IKOs forankringspunkt, nemlig skjæringspunktet mellom kirke og samfunn. Helt fra 1945 er det i dette skjæringspunktet IKO har befunnet seg. Etter min mening er det også her IKO hører hjemme. Jeg husker hvordan dette for meg ble en ganske brutal opplevelse, da jeg tidlig på 1980-tallet havnet $\mathrm{i}$ heftige ideologiske diskusjoner med Human-Etisk Forbund, etter å ha levet et nokså skjermet liv som fakultetslektor i kateketikk ved Menighetsfakultetet. Livet som leder av IKO ble i langt høyere grad et liv på barrikadene - spennende og utfordrende og lærerikt.

I skjæringspunktet mellom kirke og samfunn foregår det en ideologisk kamp. Slik var det på 1940-tallet, og slik var det på 1980-tallet. Slik er det også i dag, selv om vi forledes til å tro at ideologiene er døde. Men samfunnet er ikke noe verdimessig nøytralt rom. Det er ikke bare i kirken det forkynnes. Samfunnet er et rom for forkynnelse. Kultur er forkynnelse, fordi all kultur - direkte eller indirekte - formidler et menneskesyn og et syn på livet. Det budskap kulturen i dag forkynner, er i virkeligheten meget sammensatt. Aller sterkest er det som markedskreftene forkynner. De forvalter et budskap som nærmest umerkelig sniker seg under huden på oss alle. Ikke minst gjelder det neste generasjon, de mest forsvarsløse blant oss. Enorme summer brukes på at forkynnelsen skal nå frem: «Fordi du har fortjent det ...» Det er en forkynnelse som bidrar til kroppsfiksering og kroppshysteri, ofte med psykiske lidelser som resultat. Den bygger opp under misnøye over tingenes tilstand og skaper sug etter varer og tjenester vi slett ikke trenger. Dens mantra er ustoppelig økonomisk vekst. Den bidrar sterkt til at vi i dag setter så kraftige økologiske fotavtrykk at vår blå planet $\mathrm{i}$ kosmos er i ferd med å legges øde. I skjæringspunktet mellom kirke og samfunn må IKO stå opp mot markedskreftenes budskap og forkynne Guds gode vilje for livet. IKO må gjøre det for neste generasjons skyld, for skaperverkets skyld, for livets egen skyld.

Jeg har allerede sagt at IKO er en sjelden blomst i vår kirke-hage. Det handler for meg ikke minst om dette: Intet annet arbeidslag sentralt i Den norske kirke har sin sjel så dypt og bredt rotfestet i skjæringspunktet mellom kirke og samfunn som nettopp IKO. Eller kanskje vi skulle si: Intet annet arbeidslag er som 
IKO kalt til å leve i skjæringspunktet mellom kirke og samfunn. Med det vil jeg ha sagt: Det er ikke uten videre gitt at IKO gjør det. Det er et kall å prøve seg på, igjen og igjen, når virksomheten skal tilrettelegges. Det er IKOs egen historie som kaller på oss og sier: Her i skjæringspunktet mellom kirke og samfunn - hører du fremdeles hjemme! Å forholde seg til dette kall, er kanskje selve nøkkelutfordringen for IKO ved 70-årsjubileet.

\section{SJÅ FRAM!}

La meg liste opp noen av de viktige utfordringene jeg ser for meg for IKO i tiden som kommer.

1. Vi må våge å la oss utfordre av det som naturlig nok bør fylle oss alle med uro. Vi skal til de synkende dåpstall i vår kirke. Jeg tenker da ikke på at tallene relativt sett synker, fordi andelen som tilhører Den norske kirke i det flerreligiøse Norge naturlig nok synker. Nei, jeg tenker på de tusener på tusener som er medlemmer i vår kirke, men som lar være å døpe barna sine, slik at disse på et gitt tidspunkt umerkelig forsvinner ut av kirken, uten at noen vet hvorfor de blir borte, eller hvor hen de drar. Det vi derimot vet, er at antall som unge som blir døpt i forbindelse med konfirmasjonstiden, er langt lavere enn tallet på dem som umerkelig blir borte. Er det mulig å snu denne trenden? Mye av det gode IKO gjør i dag, handler jo nettopp om dette. Likevel ser vi at utviklingen går sin gang. Kan vi gjøre mer? Jeg er sikker på at vi kan: - Vi kan understreke sterkere at det ikke å døpe barnet sitt, er et aktivt verdivalg og ikke en nøytral handling. - Vi kan gjøre mer for å gi foreldre mot på og hjelp til å gå aktivt inn i rollen som dåpsopplæringens allmennpraktikere. Ingen kan ta denne oppgaven fra foreldrene. Det er kirkens store fristelse at den tror den kan overta foreldrenes oppgave, ja deres gudgitte kall. Kirkens oppgave er å støtte og hjelpe foreldrene underveis. Det forstod Luther. Hans Lille katekisme var i virkeligheten ment som en håndsrekning til foreldrene med tanke på trosopplæringen på hjemmebane. Er det på tide med en ny katekisme som støtte for foreldrene? Er det en oppgave for IKO å gå i gang med dette, ikke minst når vi tenker på det store Luther-jubileet som venter i 2017? Eller kommer 2017 altfor snart, slik at jubileet heller skal brukes som satsplanke for arbeidet med en ny katekisme? Det kan i hvert fall ikke være tvil om at foreldrene trenger mot på og hjelp til den oppgaven som i eminent forstand er deres. - Trosopplæring på hjemmebane handler også om ritualer - ved bordet og ved sengekanten. Husker jeg ikke feil, sier den kjente danske presten og forfatteren Johannes Møllehave et sted at er det noe han virkelig angrer på, er det at han som barn av 68-generasjonen kastet bordbønnen på dør. Selv prestehjemmet ble et ritualfattig hjem. Er det da underlig om dagens folkekirkehjem er fattige på religiøse ritualer som kan gi livet retning og bærekraft. - Helt til slutt en liten kjepphest: Hvordan kan vi i sterkere grad bygge bro mellom søndagsskolen (ingen menighet uten søndagsskole, helst som en del av gudstjenesten!), familiegudstjenesten og trosopplæringen på hjemmebane? Kanskje er det noe med søndagens karakter som kan få lyde gjennom hele uken hjemme, i form av en bønn, en sang eller noe å tenke på ... Kanskje er det noe som kan skrives på gudstjenestearket som alle kan ta med hjem, med tanke på uken som kommer? 
2. IKO må insistere på at kristendommen i det norske samfunn er til stede som noe mer enn religion. Den er til stede som kulturarv. Den har spilt en avgjørende sivilisatorisk rolle som utgjør en forenende kraft i det flerkulturelle og flerreligiøse Norge. Alle de store verdensreligionene har i virkeligheten hatt en slik sivilisatorisk rolle, der de har slått rot. ${ }^{1}$ Det kan ikke være noen tvil om at det er kristendommen som har utgjort denne kraften i den vestlige kultur. En av vår tids største filosofer, tyskeren Jürgen Habermas, som omtaler seg selv som «religiøst umusikalsk», har sagt det slik: «Kristendommen har ikke bare vært en forløper eller katalysator for den moderne tids normative selvforståelse. Idealet om universell likhet - som har gitt opphav til idealene om frihet og solidarisk samliv, om autonom livsførsel og frigjøring, om individuell moral basert på samvittigheten, menneskeretter og demokrati - er en direkte arv fra jødisk rettferdighetsetikk og kristen kjærlighetsetikk ... I møte med de aktuelle utfordringer som de postnasjonale konstellasjoner representerer, fortsetter vi å dra veksler på denne arv. Alt annet er ørkesløst postmoderne prat. $\gg^{2}$ Det er ikke kristendommen som religion, men dens rolle som kulturarv, som er nedfelt i Grunnlovens $\$ 2$ : «Værdigrunnlaget forbliver vor kristne og humanistiske arv. Denne Grundlov skal sikre Demokratiet, Rettsstaten og Menneskerettighederne.» Med en spissformulering kunne vi gjerne si: Norge er et flerreligiøst, kristent land. Konsekvensen av dette må være at IKO i sitt arbeid er opptatt av kristendommen både som religion og som kulturarv, med betydning for hele skolens virksomhet. En annen konsekvens må være at IKO arbeider for å sikre denne kulturarv en selvfølgelig plass i grunnutdanningen for alle lærere og førskolelærere i landet vårt. Som kulturarv hører kristendommen så å si til skolens sjel. Som kulturarv bør den derfor naturlig komme til uttrykk i flere av skolens fag, som norsk, samfunnsfag og musikk. IKO må insistere på dette, ikke minst $\mathrm{i}$ kontakt og samarbeid med barnehage og skole og landets utdanningsinstitusjoner.

3. Snakk opp alle som arbeider i skole og barnehage, snakk opp alle foreldre, snakk opp menighetens trosopplærere. IKO har alltid sagt: «Det gjelder barnet!» Men nettopp derfor må IKO snakke opp alle voksne som har med barn og unge å gjøre, alle som skal følge dem et stykke på livsveien. Som mange av dere vet, flyttet jeg til Trondheim etter å ha vært leder av IKO. Tjenesten som biskop gav meg unike muligheter til å føre videre sentrale engasjementer fra mine år ved IKO, ikke minst i forhold til lærere og førskolelærere. Jeg har møtt flere tusen lærere og førskolelærere i visitassammenheng, og alltid har det vært en hovedoppgave for meg: Å snakke opp deres betydning for barna og de unge. I den sammenheng brukte jeg ofte begrepet kall. Jeg merket hvordan mange av dem begjærlig grep dette ordet. Jeg tror de opplevde seg sett og forstått slik de innerste inne ønsket å forstå seg selv, om de bare våget. Kanskje var det slik at ordet kall åpnet en dør til et rom som hittil hadde vært lukket, og som ingen - og aller minst skolen eller samfunnet - hadde hjulpet dem til å åpne. Men når alt kom til alt, tror jeg det var slik mange av dem jeg møtte, innerst inne

1 Knut A. Jacobsen (red): Verdensreligioner i Norge, Oslo 2011, side 16

2 Jürgen Habermas i boken Times of Transitions, Cambridge 2006, side $150 \mathrm{f}$. 
tenkte om sin gjerning: Det er barna og de unge, det er livet selv som har kalt på meg, og jeg har latt meg kalle. I skjæringspunktet mellom kirke og samfunn må IKO lete etter ord som får mennesker til å skinne, slik det kan skje når deres gjerning snakkes opp. Intet ord er bedre egnet til dette enn ordet kall.

Jeg går inn for landing med følgende ord: En hagefest må vel sies å være en relativt beskjeden ramme rundt et 70-årsjubileum.
Jeg tar det som et tegn på at IKO ikke har tenkt å gå inn for landing. Det er bra! Alt dere unner dere, er en liten velfortjent pust i bakken ved denne milesteinen. I disse pilegrimstider hilser jeg dere med et keltisk velsignelsesønske for vandringen videre, hele tiden i skjæringspunktet mellom kirke og samfunn: «May God bless you till the next milestone - and beyond.»

\section{Finn Wagle}

Tidligere instituttstyrer/biskop em. 